\title{
MENINGKATKAN PEMAHAMAN KONSEP BILANGAN MELALUI MODEL PEMBELAJARAN NUMBERED HEAD TOGETHER (NHT) PADA KELOMPOK A1 TK MADUKISMO
}

\author{
Ni Made Ary Astuti, ppg sm3t pg paud-uny \\ arvastuti13@gmail.com
}

\begin{abstract}
Abstrak
Penelitian ini bertujuan untuk mengetahui peningkatan pemahaman konsep bilangan melalui model pembelajaran Numbered Head Together (NHT) pada anak kelompok A1 semester ganjil tahun pelajaran 2016/2017 di TK Madukismo Bantul yang berjumlah 17 orang anak, terdiri dari 9 orang anak perempuan dan 8 orang anak laki-laki. Data mengenai pemahaman konsep bilangan pada anak dikumpulkan dengan menggunakan metode observasi. Hasil analisis data menunjukkan bahwa terjadi peningkatan kemampuan pemahaman konsep bilangan melalui model pembelajaran Numbered Head Together (NHT). Dari sebelum tindakan diketahui persentase pemahaman konsep bilangan anak pada kategori baik mencapai 17,64\% yaitu sebanyak 3 anak, siklus I persentase kemampuan pemahaman konsep bilangan pada kategori baik mencapai 35,29\% yaitu sebanyak 6 anak, sedangkan pada siklus II persentase kemampuan pemahaman konsep bilangan pada kategori baik mencapai 52,94\% yaitu sebanyak 9 anak dan pada kategori sangat baik mencapai $29,41 \%$ yaitu sebanyak 5 anak. Jadi peningkatan pemahaman konsep bilangan anak mencapai 82,35\% yaitu sebanyak 14 anak pada kategori baik dan sangat baik.
\end{abstract}

Kata kunci: pemahaman konsep bilangan, model pembelajaran Numbered Head Together (NHT).

\section{IMPROVING THE NUMERICAL CONCEPT COMPREHENSION THROUGH NUMBERED HEAD TOGETHER (NHT) LEARNING MODEL TO GROUP A1 TK MADUKISMO}

\begin{abstract}
The aim of this research is to know the increase the understanding of numeral concept through the model of learning Numbered Head Together (NHT) in the Al group of odd semester in the 2016/2017 academic year at Kindergarten Madukismo Bantul consisting of 17 children; 9 girls and 8 boys. The data were collected through observation method. The result of data analysis shows that there was an increase in understanding of numeral concept through the model of learning Numbered Head Together (NHT).Before the action, the percentage of the childrens' understanding of numeral concept in a good category reached $17.64 \%$ as many as 3 children. In the first cycle percentage of the understanding of numeral concept in both categories reached $35.29 \%$ that was as many as 6 children, whereas in the second cycle the percentage in good category reached $52.94 \%$ that was as many as 9 children and in very good category reached $29.41 \%$ that was 5 children. As a result, the improvement of the childrens' understanding of numeral concept reached $82.35 \%$ that was as many as 14 children in good category and very good category.
\end{abstract}

Keywords: Understanding of numeral concept, the model of learning Numbered Head Together (NHT).

PENDAHULUAN

Pendidikan anak usia dini merupakan pendidikan yang sangat penting, karena di usia ini sangat menentukan perkembangan dan arah masa depan seorang anak. Di usia inilah anak-anak harus membentuk kesiapan dirinya menghadapi masa sekolah. Menurut Undang-Undang nomor 20 tahun 2003 tentang sistem 
Pendidikan Nasional Pasal 1 nomor 14 menyatakan bahwa, pendidikan Anak Usia Dini (PAUD) adalah suatu upaya yang ditujukan kepada anak sejak lahir sampai dengan usia enam tahun yang dilakukan melalui pemberian rangsangan pendidikan untuk membantu pertumbuhan dan perkembangan jasmani dan rohani agar anak memiliki kesiapan dalam memasuki pendidikan lebih lanjut. Taman kanak-kanak untuk satuan pendidikan bagi anak usia empat sampai enam tahun dengan berbagai jenis layanan sesuai dengan kondisi dan kemampuan yang ada, baik dalam jalur pendidikan formal maupun non formal.

Selain itu menurut Yamin \& Sanan (2012:2) juga mengatakan bahwa "hakekat pendidikan anak usia dini adalah periode pendidikan yang sangat menentukan perkembangan dan arah masa depan seorang anak sebab pendidikan yang dimulai dari usia dini akan membekas dengan baik jika pada masa perkembangannya dilalui dengan suasana yang baik, harmonis, dan menyenangkan".

Berdasarkan hasil observasi pada kelompok A1 di TK Madukismo tanggal 15 april 2016, peneliti menemukan kegiatan pembelajaran yang dilaksanakan menggunakan sistem kelompok. Anak duduk dalam satu kelompok dan bergiliran mengerjakan tugas-tugas yang diberikan guru sesuai dengan urutan kelompok. Kegiatan pada masing-masing kelompok berbeda-beda, mulai dari mewarnai, menebalkan huruf dan mengurutkan lambang bilangan. Pada kegiatan mengurutkan lambang bilangan dengan kartu angka bergambar, terlihat hanya 1 atau 2 anak saja yang mengerjakannya. Anak lainnya cenderung hanya mengamati gambar-gambar pada kartu angka, diam tidak mengerjakan atau bermain dengan temannya. Ketika peneliti mencoba melakukan tanya jawab apakah anak mampu membilang dari 1-10, ternyata masih banyak anak yang terbolak-balik menyebutkannya. Saat peneliti menunjuk angka dan menanyakan pada anak hanya 1 atau 2 anak yang bisa menjawab dengan benar. Pemahaman anak terhadap konsep bilangan dapat dikatakan masih kurang. Anak juga terlihat bosan dengan teknik pemberian tugas yang diberikan, sehingga lebih memilih bermain dengan teman lainnya.

Berdasarkan permasalahan di atas, untuk meningkatkan pemahaman konsep bilangan pada anak perlu dilakukan suatu model pembelajaran yang menarik untuk anak. Salah satu model pembelajaran yang dapat digunakan yaitu Numbered Head Together (NHT), yang pertama kali dikembangkan oleh Spenser Kagen (1993). Model pembelajaran Numbered Head Together (NHT) ini memiliki kelebihan dapat membuat anak menjadi aktif karena mengerjakan tugas bersamasama dengan temannya. Dengan model pembelajaran ini, selain mengenalkan angka pada anak dengan penomoran juga dapat memberikan motivasi dalam menyelesaikan kegiatan khususnya pada pemahaman konsep bilangan. Maka dari itu perlu dilakukan penelitian yang berjudul "meningkatkan pemahaman konsep bilangan melalui model pembelajaran Numbered Head Together (NHT) pada kelompok A1 TK Madukismo".

Banyak ahli mengatakan anak terlahir dengan kemampuan dan kreativitas yang berbeda-beda. Salah satu kemampuan yang perlu dikembangkan sejak dini yaitu kemampuan kognitif. Pengertian kognitif meliputi aspek-aspek kemampuan yaitu, bagaimana individu itu memperhatikan, mengamati, mengingat, memikirkan dan menghafal serta bentuk-bentuk mental lainnya. Kognitif seringkali diartikan sebagai kecerdasan atau berpikir, dimana perkembangan kognitif menunjukkan perkembangan dari cara anak berpikir dalam memahami konsep dan memecahkan masalah sehari-hari (Soemiarti Patmonodewo, 2003:27). Jadi dapat disimpulkan bahwa perkembangan kognitif adalah pengertian yang luas 
mengenai berpikir dan mengamati serta merupakan tingkah laku yang mengakibatkan orang memperoleh pengetahuan atau yang dibutuhkan untuk menggunakan pengetahuan. Perkembangan kognitif menunjukkan perkembangan dari cara anak berpikir. Kemampuan anak untuk mengolah berbagai informasi untuk menyelesaikan masalah.

Piaget (Soemiarti Patmonodewo, 2003:28) menjelaskan perkembangan kognitif terdiri dari empat tahapan perkembangan yaitu tahapan sensorimotor, tahapan praoperasional, tahapan operasional konkret dan operasional formal. Tahapantahapan tersebut berkaitan dengan pertumbuhan kematangan dan pengalaman anak. Walaupun pada dasarnya usia anak prasekolah dikaitkan dengan tahapan perkembangan dari piaget, yakni tahap sensorimotor (0-2 tahun) dan tahap praoperasional (2-7 tahun). Namun terdapat juga faktor-faktor yang dapat mempengaruhi perkembangan kognitif.

Beberapa faktor yang mempengaruhi kemampuan kognitif menurut Susanto, (2011:59) adalah sebagai berikut. a. Faktor hereditas / keturunan dikatakan bahwa manusia lahir sudah membawa potensipotensi tertentu yang tidak dapat dipengaruhi oleh lingkungan; b. Faktor lingkungan perkembangan manusia sangat ditentukan oleh pengalaman dan pengetahuan yang diperolehnya dilingkungan hidupnya; c. Faktor Kematangan tiap organ (fisik maupun psikis); d. Pembentukan ialah segala keadaan diluar diri seseorang yang mempengaruhi perkembangan intelegensi; e. Minat dan bakat menyatakan perbuatan kepada suatu tujuan dan merupakan dorongan untuk berbuat lebih baik lagi; f. Kebebasan yaitu kebebasan manusia berpikir.

Selain itu menurut Peraturan Menteri Pendidikan dan Kebudayaan RI No.146, Tahun 2014 menyatakan bahwa: Tingkat Pencapaian Perkembangan (TPP) pada anak usia 4-6 tahun terbagi menjadi tiga yaitu: a. Belajar dan pemecahan masalah, yang terdiri dari, 1) mengenal benda berdasarkan fungsi, 2) menggunakan benda-benda sebagai permainan simbolik, 3) mengenal konsep sederhana, 4) mengetahui konsep banyak dan sedikit, 5) mengkreasikan sesuatu sesuai dengan idenya, 6) mengamati benda, 7) mengenal pola kegiatan, 8) memahami posisi dalam ruang lingkup social, b. Berfikikir logis , yang terdiri dari, 1) mengklasifikasikan benda berdasarkan fungsi, 2) mengenal gejala sebab akibat, 3) mengklasifikasikan benda yang sam/sejenis, 4) mengenal pola ABC$\mathrm{ABC}, 5)$ mengurutkan benda berdasarkan 5 seriasi ukuran atau warna, c. berfikir simbolik, yang terdiri dari, 1) membilang banyak benda 1-10, 2) mengenal konsep bilangan, 3) mengenal lambang bilangan, dan 4) mengenal lambang huruf. Berdasarkan hal tersebut maka dapat disimpulkan bahwa karakteristik anak usia 4-5 tahun atau pada kelompok A rata-rata sudah mampu mengenal dan memahami konsep lambang bilangan satu sampai dengan sepuluh.

Bilangan merupakan suatu ukuran dari besaran, tetapi juga dipakai dalam suatu cara abstrak (tak terwujud) tanpa menghubungkannya dengan berapa banyak atau pengukurannya (Sudaryanti 2006:1). Menurut Baharin Shamsudin (2002:16) bilangan merupakan jumlah atau kuantitas suatu himpunan benda tertentu. Pakasi dalam Sriningsih (2009:45) memaparkan bahwa ada empat bagian yang merupakan konsep matematika antara lain nama, urutan, lambang dan jumlah.

Peraturan menteri dan kebudayaan RI nomor 46 tahun 2014, untuk anak usia 4-5 tahun berada pada tahap mengenal konsep bilangan 1-10. Kemampuan anak dalam memahami konsep bilangan berada pada tahap menyebut urutan bilangan dari 1-10, membilang (mengenal konsep bilangan dengan benda benda) sampai 10, menghubungkan/memasangkan lambang bilangan dengan benda-benda hingga 10 
(Eli Misyati, 2013: 37). Jadi kemampuan mengenal lambang bilangan merupakan kesanggupan pada anak untuk mengetahui simbol yang melambangkan banyaknya benda.

Berdasarkan pengertian-pengertian di atas maka dapat disimpulkan bahwa kemampuan aritmatika merupakan salah satu pengembangan kognitif yang mencangkup pengetahuan dalam pemahaman konsep bilangan, dimana konsep bilangan itu sendiri mencakup membilang dengan benda, mengurutkan bilangan, mengenal lambang bilangan, serta memasangkan banyak benda dengan simbol angka.

Salah satu konsep matematika yang penting dikuasai anak adalah pemahaman konsep bilangan, sebab akan menjadi dasar pemahaman untuk pengembangan konsep matematika yang lainnya. Dalam pengenalan bilangan hendaknya disesuaikan dengan karakteristik perkembangan anak.

Pemahaman konsep bilangan pada anak anak usia 4-5 tahun menurut pendapat Ahmad Susanto (2011: 107), adalah sebagai berikut. (a) Membilang, (b) menyebut urutan bilangan 1-20, (c) membilang (mengenal konsep bilangan dengan bendabenda, (d) menghubungkan /memasangkan lambang bilangan dengan benda-benda hingga 10, (e) membedakan dan membuat dua benda yang sama jumlahnya, yang tidak sama, lebih banyak dan lebih sedikit.

Berdasarkan pemaparan di atas dapat ditarik kesimpulan bahwa karakteristik pemahaman konsep bilangan pada usia 4-5 tahun meliputi membilang banyak benda satu sampai sepuluh, mengenal lambang bilangan (angka), serta mengurutkan lambang bilangan (angka) 1-10. Kisi-kisi pemahaman konsep bilangan anak dalam penelitian ini dapat dilihat pada tabel berikut.

Tabel 1. Kisi-kisi penelitian tindakan kelas untuk meningkatkan pemahaman konsep bilangan anak

\begin{tabular}{llll}
\hline Variabel & Sub & Indikator & Keterangan \\
& Variabel & & \\
\hline
\end{tabular}

\begin{tabular}{|c|c|c|c|}
\hline & $\begin{array}{l}\text { Menyebut } \\
\text { kan } \\
\text { bilangan }\end{array}$ & $\begin{array}{l}\text { Membilang } \\
\text { banyak benda } \\
1-10\end{array}$ & $\begin{array}{l}\text { Membilang } \\
\text { benda } 1-10\end{array}$ \\
\hline $\begin{array}{l}\text { Pemah } \\
\text { aman } \\
\text { konsep } \\
\text { bila }\end{array}$ & $\begin{array}{l}\text { Mengenal } \\
\text { lambang } \\
\text { bilangan }\end{array}$ & $\begin{array}{l}\text { Menunjukkan } \\
\text { lambang } \\
\text { bilangan }\end{array}$ & $\begin{array}{l}\text { Mengambil } \\
\text { gambar } \\
\text { angka sesuai } \\
\text { perintah }\end{array}$ \\
\hline ngan & $\begin{array}{l}\text { Mengurut } \\
\text { kan }\end{array}$ & $\begin{array}{l}\text { Mengurutkan } \\
\text { lambang } \\
\text { bilangan 1-10 }\end{array}$ & $\begin{array}{l}\text { Mengurutka } \\
\mathrm{n} \text { angka yang } \\
\text { acak } 1-10\end{array}$ \\
\hline
\end{tabular}

Kemampuan anak dapat berkembang sesuai dengan tahapan perkembangannya, untuk itu seorang guru perlu mengetahui model pembelajaran apa yang hendaknya diberikan pada anak. Menurut Mills (dalam Yamin \& Sanan, 2012:21) berpendapat bahwa, "pengertian model pembelajaran merupakan landasan praktik pembelajaran hasil penurunan teori psikologis pendidikan dan belajar, yang dirancang berdasarkan proses aalisis yang diarahkan pada implementasi kurikulum dan implikasinya pada tingkat operasional di depan kelas". Lebih lanjut Trianto (2007:7) menyatakan bahwa, "model pembelajaran adalah kerangka konseptual yang melukiskan prosedur yang sistematis dalam mengorganisasikan pengalaman belajar untuk mencapai tujuan belajar tertentu dan berfungsi sebagai pedoman bagi para perancang pembelajaran dan para pengajar dalam merencanakan aktivitas belajar mengajar.

Dari definisi model pembelajaran diatas dapat disimpulkan bahwa model pembelajaran merupakan suatu rencana atau pola yang dapat digunakan oleh para perancang pembelajaran dan para pengajar sebagai pedoman dalam merencanakan aktivitas belajar mengajar dikelas dengan mengacu pada pendekatan pembelajaran yang digunakan, tujuan-tujuan pengajaran, tahap-tahap dalam kegiatan pembelajaran, lingkungan pembelajaran, dan pengelolaan kelas untuk mencapai tujuan belajar.

Model pembelajaran yang sering digunakan oleh guru dalam mengajar menurut Arends (dalam Trianto, 
2009:25) yaitu “ (1) presentasi, (2) pengajaran langsung, (3) pengajaran konsep, (4) pembelajaran kooperatif, (5) pengajaran berdasarkan masalah dan (6) diskusi kelas". Dalam mengajarkan suatu pokok bahasan atau materi tertentu kepada peserta didik hendaknya guru memilih model pembelajaran yang sesuai dengan tujuan yang akan dicapai.

Salah satu model pembelajaran yang dapat diberikan pada anak usia dini adalah model pembelajaran kooperatif. Model pembelajaran kooperatif (cooperative learning) menurut Mulyani dan Johan (1999:42-43) merupakan strategi belajar dengan sejumlah siswa sebagai anggota kelompok kecil yang tingkat kemampuannya berbeda untuk mencapai tujuan belajar tertentu. "Model pembelajaran kooperatif adalah bentuk pembelajaran dengan cara siswa belajar dan bekerja dalam kelompok-kelompok kecil secara kolaboratif yang anggotanya terdiri dari empat sampai enam orang dengan struktur kelompok yang bersifat heterogen" (Rusman, 2012). Berdasarkan pendapat diatas, dapat disimpulkan bahwa pembelajaran kooperatif menekankan peserta didik pada perilaku bersama. Dalam bekerja sama yang bertujuan untuk saling membantu satu sama lain, menghormati pendapat orang lain, dan selalu bekerja sama untuk menambah pengetahuannya.

Salah satu model pembelajaran kooperatif adalah Numbered Head Together $(N H T)$. Model pembelajaran kooperatif tipe Numbered Head Together (NHT) dikembangkan pertama kali oleh Spencer Kagan (1992). Teknik ini memberikan kesempatan kepada anak didik untuk saling membagikan ide-ide dan mempertimbangkan jawaban yang paling tepat, mendorong anak didik meningkatkan kerjasama serta dapat digunakan untuk semua tingkatan usia (Yudha \& Rudyanto, 2005:74). Pengertian pembelajaran kooperatif tipe Numbered Head Together (NHT) menurut Herdian (dalam Sulistiyowati, 2012) adalah "suatu tipe pembelajaran kooperatif yang menekankan pada struktur khusus yang dirancang untuk mempengaruhi pola interaksi anak dan memiliki tujuan untuk meningkatkan penguasaan akademik".

Dari definisi model pembelajaran Numbered Head Together (NHT) di atas maka dapat disimpulkan bahwa model pembelajaran Numbered Head Together (NHT) merupakan pendekatan yang dikembangkan untuk membuat anak lebih aktif sehingga dapat bekerjasama dan selalu siap untuk memberikan jawaban terhadap pertanyaan yang diberikan oleh guru.

$$
\text { Adapun ciri-ciri model }
$$

pembelajaran Numbered Head Together (NHT) menurut Apriliana (2013:23) yaitu "(1) kelompok heterogen, (2) setiap anggota kelompok memiliki nomor kepala yang berbeda-beda dan (3) berpikir bersama (Heads Together)". Model pembelajaran Numbered Head Together (NHT) ini secara tidak langsung melatih anak untuk saling berbagi informasi, mendengarkan dengan cermat serta berbicara dengan penuh perhitungan sehingga anak lebih produktif dalam pembelajaran.

Terdapat persepsi yang tertanam dalam dunia pendidikan dan juga menjadi pemikiran masyarakat. Persepsi yang dimaksud adalah anggapan tentang tugas guru untuk mengajar dan memberikan pelajaran-pelajaran serta informasi-informasi dan pengetahuan. Semestinya siswa belajar dalam situasi sewajarnya sehingga proses transfer ilmu dari guru ke siswa dapat berjalan sesuai dengan tujuan yang diinginkan. Penggunaan model pembelajaran yang tepat juga dapat mempengaruhi proses pembelajaran.

Dalam hal ini model pembelajaran yang dimaksud adalah model pembelajaran Numbered Head Together (NHT), yang merupakan suatu model pembelajaran yang lebih mengedepankan kepada aktivitas anak dalam mencapai, mengolah dan melaporkan informasi dari berbagai sumber yang akhirnya 
dipresentasikan di depan kelas sehingga hasil belajar anak meningkat (Purwanti, 2013:3).

Masalah yang ingin peneliti bahas dalam penelitian ini adalah bagaimana Numbered Head Together (NHT) dapat meningkatkan pemahaman konsep bilangan pada anak kelompok A1 semester ganjil tahun pelajaran 2016/2017 di TK Madukismo, Bantul?. Oleh karena itu, penelitian ini diarahkan untuk mencari tahu peningkatan pemahaman konsep bilangan melalui model pembelajaran Numbered Head Together (NHT) pada anak kelompok A1 semester ganjil tahun pelajaran 2016/2017 di TK Madukismo.

\section{METODE PENELITIAN Jenis Penelitian}

Jenis penelitian ini merupakan Penelitian Tindakan Kelas (Classroom Action Research). Model penelitian tindakan kelas yang dipilih adalah model penelitian Kemmis dan Mc Taggart yaitu model spiral yang dilakukan secara berulang dan berkelanjutan, artinya proses pembelajaran yang semakin lama semakin meningkat hasil belajarnya.

Penelitian dilaksanakan pada semester genap tahun pelajaran 2013/2014 pada 3 maret sampai 3 Mei tahun 2014. Penelitian tindakan kelas ini dilaksanakan pada kelompok B3 di TK Santa Maria Singaraja, Kecamatan Buleleng, Kabupaten Buleleng.

Penelitian ini dilaksanakan secara kolaboratif, artinya peneliti tidak melakukan penelitian sendiri namun berkolaborasi dengan guru kelas, yaitu guru kelompok A1 TK Madukismo untuk melakukan perbaikan dan perubahan model pembelajaran. Penelitian ini dimaksudkan untuk meningkatkan pemahaman konsep bilangan melalui model pembelajaran Numbered Head Together (NHT).

\section{Waktu dan Tempat Penelitian}

Penelitian ini dilaksanakan pada semester I tahun ajaran 2016/2017 tepatnya bulan Agustus sampai November 2016, dan dilaksanakan di kelompok A1 TK
Madukismo yang beralamat di Padokan, Tirtonirmolo, Kasihan Bantul.

\section{Subjek Penelitian}

Subjek penelitian ini adalah anakanak di kelompok A1 TK Madukismo dengan jumlah 17 anak, terdiri 8 anak laki-laki dan 9 anak perempuan. Objek penelitian adalah variabel penelitian, yaitu sesuatu yang merupakan inti dari problematika penelitian (Suharsimi Arikunto, 2006: 29). Objek dalam penelitian ini adalah pemahaman konsep bilangan pada kelompok A1.

\section{Prosedur}

Penelitian ini dilaksanakan dalam beberapa siklus, setiap siklus terdiri dari empat langkah seperti yang dikemukakan Kemmis dan Mc Taggart. Setelah satu siklus selesai kemudian dilanjutkan siklus selanjutnya apabila indikator keberhasilan belum tercapai. Dalam setiap siklus terdapat 3 tahapan yang perlu dilakukan yaitu tahap perencanaan, tahap tindakan/observasi dan refleksi. Pada tahap perencanaan peneliti menjelaskan tentang apa, mengapa, kapan, di mana, oleh siapa, dan bagaimana pelaksanaan tindakan tersebut dilakukan. Dalam rencana tindakan ini, peneliti menyiapkan perangkat pembelajaran (RPPH), media, instrument penelitian dan alat-alat pendukung penelitian lainnya. Pada tahap tindakan, peneliti melaksanakan perencanaan pembelajaran yang telah dirancang. Peneliti juga perlu melakukan pemantauan bersama dengan guru dan teman sejawat. Pengamatan dilaksanakan oleh peneliti selama proses pembelajaran berlangsung terhadap aktivitas siswa. Pengamatan dilakukan melalui wawancara dan mengisi lembar observasi yang telah dipersiapkan.

Selanjutnya Refleksi dilakukan berdasarkan hasil evaluasi yang telah dilakukan dengan mengungkapkan hasil pembelajaran pada waktu tindakantindakan yang dilakukan siswa. Hasil refleksi ini dapat dijadikan perbaikan pada siklus berikurtnya. 


\section{Data, Instrument dan Teknik Pengumpulan Data}

Metode pengumpulan data adalah cara-cara yang dapat digunakan oleh peneliti untuk mengumpulkan data. Menurut Suharsimi Arikunto (2006: 150) metodemetode yang digunakan untuk mengumpulkan data ada dua yaitu tes dan non tes. Data dalam penelitian ini melalui observasi dan dokumentasi. Observasi adalah pengamatan dan pencatatan suatu

objek dengan sistematika fenomena yang diselidiki (Sukandarrumidi, 2002: 69). Kisikisi observasi yang digunakan sebagai dasar pada penelitian ini menggunakan variabel pemahaman konsep bilangan. Sub variabel yang digunakan terdiri dari menghitung bilangan, mengenal angka, serta mengurutkan.

Tabel 2. Kisi-kisi lembar observasi pemahaman konsep bilangan

\begin{tabular}{llll}
\hline Variabel & Sub Variabel & Indikator & Keterangan \\
\hline & $\begin{array}{l}\text { Menyebut } \\
\text { kan bilangan }\end{array}$ & $\begin{array}{l}\text { Membilang } \\
\text { banyak } \\
\text { benda 1-10 }\end{array}$ & $\begin{array}{l}\text { Membilang } \\
\text { benda 1-10 }\end{array}$ \\
& $\begin{array}{l}\text { Mengenal } \\
\text { Menunjukka }\end{array}$ & $\begin{array}{l}\text { Mengambil } \\
\text { Pemaham }\end{array}$ & $\begin{array}{l}\text { lambang } \\
\text { bembar }\end{array}$ \\
$\begin{array}{l}\text { an konsep } \\
\text { bilangan }\end{array}$ & bilangan & bilangan & $\begin{array}{l}\text { angka } \\
\text { sesuai } \\
\text { perintah }\end{array}$ \\
& Mengurutkan & $\begin{array}{l}\text { Mengurut } \\
\text { kan lambang } \\
\text { bilangan 1- }\end{array}$ & $\begin{array}{l}\text { Mengurut angka } \\
\text { yang acak } \\
\end{array}$ \\
& & 10 & $1-10$ \\
\hline
\end{tabular}

Dokumentasi merupakan catatan peristiwa yang sudah berlalu, bisa berbentuk tulisan, gambar atau karya-karya monumental dari seseorang (Sugiyono, 2009: 329). Pada penelitian ini peneliti akan mengambil beberapa dokumen dari TK Madukismo seperti RKH (Rencana Kegiatan harian, foto media pembelajaran, dan foto kegiatan siswa.

\section{Teknik Analisis Data}

Teknik analisis data yang digunakan adalah teknik analisis kualitatif, teknik ini digunakan untuk mengetahui tinggi rendahnya pemahaman konsep bilangan, melalui model pembelajaran Numbered Head Together (NHT). Data yang dianalisis berupa data hasil check list mengenai pemahaman anak pada konsep bilangan melalui metode pembelajaran Numbered Head Together (NHT). Dari hasil penelitian yang telah dilakukan selanjutnya dapat dihitung dengan persentase. Disamping itu seluruh data yang digunakan untuk mengambil kesimpulan dan tindakan yang dilakukan menggunakan rumus Ngalim Purwanto (2006:102) yaitu sebagai berikut.

Rumus :
Keterangan :

NP : Nilai persen yang dicari/ diharapkan

$\mathrm{R}$ : Skor mentah yang diperoleh siswa

SM : Skor maksimum ideal dari tes yang bersangkutan

Data penelitian dapat diinterpretasikan dalam lima tingkatan, yaitu:

1. Kesesuaian kriteria (\%) : $0-20=$ Kurang sekali

2. Kesesuaian kriteria (\%) : $21-40=$ Kurang

3. Kesesuaian kriteria $(\%) \quad: \quad 41-60=$ Cukup

4. Kesesuaian kriteria $(\%) \quad: \quad 61-80=$ Baik

5. Kesesuaian kriteria $(\%) \quad: \quad 81-100=$ Sangat baik (Suharsimi Arikunto, 2010: 44).

Indikator keberhasilan hasil penelitian tindakan kelas ini ditandai dengan meningkatnya pemahaman konsep bilangan anak. Peningkatan keberhasilan dapat ditandai dengan membandingkan hasil dari data awal pra penelitian (pretest) dan setelah diberikan tindakan (post test). Sebagai indikator keberhasilan anak dalam penelitian ini adalah apabila $80 \%$ atau 14 anak dari 17 anak pada Kelompok A1 di TK Madukismo mengalami peningkatan pada kriteria baik dan sangat baik dalam pemahaman konsep bilangan melalui model pembelajaran Numbered Head Together (NHT). 


\section{HASIL PENELITIAN DAN PEMBAHASAN}

Penelitian ini dilakukan di TK Madukismo yang beralamat di Padokan, Tirtonirmolo, Kasihan Bantul. Penelitian ini dilaksanakan pada semester I tahun ajaran 2016/2017 antara bulan Agustus sampai Nopember. Dalam penelitian ini, peneliti melakukan penelitian pada kelompok A1 dengan jumlah 17 anak yang terdiri dari 9 anak perempuan dan 8 anak laki-laki.

Langkah awal yang dilakukan peneliti sebelum melakukan penelitian tindakan kelas yaitu melalui pengamatan awal berupa kegiatan pra tindakan untuk mengetahui keadaan awal pemahaman konsep bilangan anak kelompok A1 TK Madukismo. Dari hasil pengamatan maupun observasi diperolah data sebagai berikut.

Tabel 3. Rekapitulasi Data Pemahaman Konsep Bilangan sebelum Tindakan

\begin{tabular}{c|l|c|c}
\hline No & \multicolumn{1}{|c|}{ Kriteria } & $\begin{array}{c}\text { Jumlah } \\
\text { Anak }\end{array}$ & Persentase \\
\hline 1 & Sangat baik & 0 & $0 \%$ \\
2 & Baik & 3 & $17,64 \%$ \\
3 & Cukup & 6 & $35,29 \%$ \\
4 & Kurang & 8 & $47,05 \%$ \\
5 & Kurang sekali & 0 & $0 \%$ \\
& Jumlah & 17 & \\
\hline
\end{tabular}

Dari rekapitulasi data pemahaman konsep bilangan di atas diperoleh data bahwa 3 orang anak masuk dalam kriteria baik, 6 orang anak masuk dalam kriteria cukup, dan 8 anak masuk dalam kriteria kurang. Hal itu menunjukkan bahwa pemahaman konsep bilangan anak masih rendah. Dari satu kelas sebanyak 47,05\% dari jumlah keseluruhan anak di kelas masih dalam kriteria kurang dan angka persentase menunjukkan pada rentang 0\%-40\%. Selain itu dari 17 anak, baru 3 anak yang memiliki pemahaman konsep bilangan yang lebih baik dibandingkan dengan anak yang lain.

Melihat dari data sebelum tindakan maka diperlukan adanya tindakan melalui model pembelajaran Numbered Head Together (NHT) untuk meningkatkan pemahaman konsep bilangan pada anak kelompok A1. Penelitian tindakan kelas pada siklus I dilaksanakan tiga kali pertemuan. Siklus I dilaksanakan pada hari Senin 3 Oktober, Rabu 5 Oktober dan Jumat 7 Oktober 2016. Tema yang digunakan pada siklus I adalah tanaman. Setelah tahap perencanaan, tindakan/observasi pada siklus I pertemuan 1,2, dan 3 dilaksanakan maka diperoleh data sebagai berikut.

Tabel 4. Rekapitulasi Data Pemahaman Konsep Bilangan Siklus I

\begin{tabular}{llcc}
\hline No & \multicolumn{1}{c}{ Kriteria } & $\begin{array}{c}\text { Jumlah } \\
\text { Anak }\end{array}$ & Persentase \\
\hline 1 & Sangat baik & 0 & $0 \%$ \\
2 & Baik & 6 & $35,29 \%$ \\
3 & Cukup & 9 & $52,94 \%$ \\
4 & Kurang & 2 & $11,76 \%$ \\
5 & Kurang sekali & 0 & $0 \%$ \\
& Jumlah & 17 &
\end{tabular}

Dari rekapitulasi data tersebut dapat dikatakan bahwa ketercapaian pada akhir Siklus I menunjukkan bahwa sudah sedikit anak yang masuk dalam kriteria kurang yaitu hanya 2 anak, kriteria cukup sebanyak 9 anak, kriteria baik sebanyak 6 anak, namun kriteria sangat baik masih belum tercapai. Walaupun demikian, berdasarkan hasil yang diperoleh dari pelaksanaan siklus I apabila dibandingkan dengan hasil yang diperoleh sebelum tindakan telah terlihat adanya peningkatan.Pada siklus I pemahaman konsep bilangan anak pada kategori baik meningkat sampai 35,29\%. Dari hasil pengamatan yang dilakukan selama siklus I ditemukan beberapa kendala yang menyebabkan hasil kemampuan pemahaman konsep bilangan anak masih perlu ditingkatkan pada siklus II. Kendala-kendala yang dihadapi seperti anak masih bingung dengan model pembelajaran Numbered Head Together (NHT), anak belum terbiasa berdiskusi, dan masih banyak anak kurang aktif mengikuti kegiatan. Maka dari itu perlu adanya perbaikan di siklus II yaitu penerapan model pembelajaran Numbered Head Together (NHT) dilaksanakan dengan 
memberikan nilai bintang kepada kelompok yang lebih dulu menjawab dengan benar dan cepat, dan Pada pemberian mahkota bernomor kepala diberikan warna yang berbeda-beda antar kelompok sehingga anak lebih focus berdiskusi dengan anggota kelompoknya. Penelitian kemudian dilanjutkan ke siklus II. Siklus II merupakan tindak lanjut dari siklus I. Pelaksanaan siklus II sama dengan siklus I yaitu 3 kali pertemuan. Setelah melakukan perencanaan dan tindakan/observasi maka diperoleh data pada siklus II sebagai berikut.

Tabel 5. Rekapitulasi Data Pemahaman Konsep Bilangan Siklus II

\begin{tabular}{c|l|c|c}
\hline No & Kriteria & $\begin{array}{c}\text { Jumlah } \\
\text { Anak }\end{array}$ & Persentase \\
\hline 1 & Sangat baik & 5 & $29,41 \%$ \\
2 & Baik & 9 & $52,94 \%$ \\
3 & Cukup & 3 & $17,65 \%$ \\
4 & Kurang & 0 & $0 \%$ \\
5 & Kurang sekali & 0 & $0 \%$ \\
& Jumlah & 17 & \\
\hline
\end{tabular}

Dari data diatas dapat dilihat sudah ada 5 anak yang mencapai kriteria sangat baik. Berdasarkan hal tersebut, maka diperoleh hasil dari pelaksanaan siklus I apabila dibandingkan dengan hasil yang diperoleh pada siklus II telah terlihat adanya peningkatan. Pada siklus II pemahaman konsep bilangan anak pada kategori baik mencapai 52,94\% dan kategori sangat baik meningkat sampai $29,41 \%$.

Berdasarkan hasil penelitian, selanjutnya akan diuraikan peningkatan secara keseluruhan hasil pemahaman konsep bilangan dari sebelum tindakan, siklus I dan siklus II . Pada kegiatan sebelum tindakan belum ada anak yang masuk dalam kriteria sangat baik, sebanyak 3 anak $(17,64 \%)$ masuk dalam kriteria baik, 6 anak $(35,29 \%)$ masuk dalam kriteria cukup dan 8 anak $(47,05 \%)$ masuk dalam kriteria kurang. Pemahaman konsep bilangan anak kelompok A1 pada tindakan Siklus I, sebanyak 6 anak $(35,29 \%)$ masuk dalam kriteria baik dan 9 anak $(52,94 \%)$ masuk dalam kriteria cukup. Jumlah keseluruhan anak yang mencapai indikator keberhasilan pemahaman konsep bilangan sebanyak 6 anak $(35,29 \%)$ sehingga perlu dilanjutkan pada siklus II dengan melakukan perbaikan pada hambatan yang ada pada Siklus I.

Setelah dilakukan perbaikan, hasil yang diperoleh untuk pemahaman konsep bilangan pada Siklus II yaitu sebanyak 5 anak $(29,41 \%)$ masuk dalam kriteria sangat baik dan 9 anak $(52,94 \%)$ masuk dalam kriteria baik. Jumlah keseluruhan anak yang termasuk dalam kriteria baik dan sangat baik sebanyak 14 anak $(82,35 \%)$. Berdasarkan uraian di atas, dapat ditegaskan bahwa melalui model pembelajaran Numbered Head Together (NHT) dapat meningkatkan pemahaman konsep bilangan pada anak kelompok A1 TK Madukismo.

\section{PENUTUP}

Sebelum dilaksanakan tindakan dapat diketahui bahwa pemahaman konsep bilangan anak pada kategori baik mencapai $17,64 \%$. Pada pelaksanaan siklus I, pemahaman konsep bilangan anak pada kategori baik mencapai $35,29 \%$. Karena pelaksanaan siklus I belum mampu mencapai kriteria keberhasilan yang ditetapkan peneliti, maka dilaksanakan siklus II. Setelah pelaksanaan siklus II, pemahaman konsep bilangan anak meningkat pada kriteria baik dan sangat baik mencapai $82,35 \%$.

Langkah-langkah pembelajaran melalui model pembelajaran Numbered Head Together (NHT) adalah 1) Guru membagi anak kedalam 3 kelompok kecil, setiap kelompok terdiri dari 5 sampai 6 anak; 2) Masing-masing anak diberikan mahkota bernomor dengan warna mahkota sesuai kelompoknya; 3) Guru mulai menjelaskan kegiatan yang bertujuan meningkatkan pemahaman konsep bilangan anak; 4) Setiap kelompok dibagikan 1 tugas yang sama dan dikerjakan bersama-sama teman satu 
kelompoknya; 5) Setelah semua kelompok selesai mengerjakan tugas yang diberikan, guru memanggil 1 anak dimasing-masing kelompok dengan nomor kepala yang sama untuk maju ke depan kelas mengulang kembali kegiatan yang dikerjakan saat berkelompok secara mandiri; 6) Semua anak di usahakan dipanggil secara bergiliran untuk melihat pemahaman konsep bilangan anak dengan praktek langsung secara mandiri di depan kelas; 7) Setelah selesai guru dapat melanjutkan kembali kekegiatan berikutnya.

Dari hasil tersebut dapat diketahui bahwa peningkatan pemahaman konsep bilangan melalui model pembelajaran Numbered Head Together (NHT) dari hasil sebelum tindakan, siklus I dan siklus II telah mencapai kriteria keberhasilan yang diharapkan peneliti.

\section{DAFTAR PUSTAKA}

Arikunto, S.,dkk. (2006). Prosedur penelitian suatu pendekatan praktik Edisi Revisi VI. Jakarta: Rineka Cipta.

Asma, N. (2006). Model pembelajaran kooperatif. Jakarta: Departemen Pendidikan Nasional Direktorat Jendral Pendidikan Tinggi.

Djiwandono, S.E.W. (2004). Psikologi pendidikan. Jakarta: PT Grasindo.

Isjoni. (2011). Model pembelajaran anak usia dini. Bandung: Alfabet.

Maryani. (2010). Meletakkan dasar-dasar pengalaman konsep matematika melalui permainan praktis di kelompok bermain. Jurnal Pendidikan Penabur-Nomor 15.

Suprijono, A. (2011). Coorperative learning. Yogjakarta: Pustaka Pelajar.

Susanto, A. (2011). Perkembangan anak usia dini. Jakarta: Kencana Prenada Media Group.
Shamsudin, B. (2002). Kamus Matematika Bergambar. Jakarta: Grasindo.

Ratri, D. K. (2013). Pengaruh model pembelajaran numbered head together terhadap hasil belajar matematika kelas $V$ materi sifat bangun ruang. Diakses tanggal 18 Juli 2016 dari http://library.ikippgrismg.ac.id/docf iles/fulltext/3cc6365ee507e46c.pdf.

Menteri Pendidikan Dan Kebudayaan. (2014). Peraturan menteri pendidikan dan kebudayaan RI nomor 146 tentang standar isi pendidikan anak usia dini.

Mutiah, D. (2010). Psikologi bermain anak usia dini. Jakarta: Kencana.

Ngatini. (2012). Peningkatan keaktifan dan hasil belajar matematika tentang fungsi melalui model pembelajaran numbered head together (NHT) bagi siswa smp. 7 (1), 151-159.

Patmonodewo, S. (2003). Pendidikan anak prasekolah. Jakarta: PT Rineka Cipta.

Purwanto, N. (2006). Prinsip-prinsip \& Tekhnik Evaluasi Pengajaran. Bandung: PT. Remaja Rosdakarya.

Sanjaya, W. (2009). Penelitian tindakan kelas. Jakarta: Kencana.

Santrock, J.W. (2012). Perkembangan masa hidup. Edisi 13 (Terjemahan Benedictine Wisdyasinta). Jakarta: Erlangga. 
Seefeldt, C. \& Wasik, B.A. (2008). Pendidikan anak usia dini. (Terjemahan Pinus Nasar) Jakarta: PT Macanan Jaya Cemerlang.

Soekarnoputri, M. (2003). Undang-undang R I nomor 20 tahun 2003 tentang sistem pendidikan nasional.

Sudaryanti. (2006). Pengenalan matematika anak usia dini. Yogyakarta: FIP UNY.

Sugiyanto. (2010). Model-model pembelakaran inovatif. Surakarta: Yuma Pustaka.

Sujiono, Y.N., dkk. (2007). Metode pengembangan kognitif. Jakarta: Universitas Terbuka.

Sulistiyowati, E. (2012). Penerapan model pembelajaran kooperatif tipe NHT dengan media konkret dalam peningkatan pembelajaran pecahan siswa kelas V SDN 1 waluyerejo. Diakses tanggal 18 Juli 2016 dari http://portalgaruda.org.download_a rtcle.php?article $=108485 \& \mathrm{val}=407$ 3 .

Sumantri, M., Permana, J. (1999). Strategi belajar mengajar. Jakarta: Departemen Pendidikan dan Kebudayaan Direktorat Jenderal Pendidikan Tinggi Proyek Pendidikan Guru Sekolah Dasar.

Suyanto, dkk. (2007). Pedoman pelaksanaan penelitian tindakan kelas (PTK) pengenalan penelitian tindakan kelas. Yogyakarta: IKIP Yogyakarta.

Suyanto, S. (2005). Dasar-dasar pendidikan anak usia dini. Yogyakarta: Hikayat Publishing. 